Article

\title{
New Circular Networks in Resilient Supply Chains: An External Capital Perspective
}

\author{
Sara Alonso-Muñoz ${ }^{1, *(\mathbb{D})}$, Rocío González-Sánchez ${ }^{1} \mathbb{D}$, Cristina Siligardi $^{2} \mathbb{D}$ and Fernando E. García-Muiña ${ }^{1} \mathbb{D}$ \\ 1 Department of Business Administration (ADO), Applied Economics II and Fundaments of \\ Economic Analysis, Rey-Juan-Carlos University, 28032 Madrid, Spain; rocio.gonzalez@urjc.es (R.G.-S.); \\ fernando.muina@urjc.es (F.E.G.-M.) \\ 2 Department of Engineering Enzo Ferrari, University of Modena and Reggio Emilia, 41125 Modena, Italy; \\ cristina.siligardi@unimore.it \\ * Correspondence: sara.alonso@urjc.es
}

Citation: Alonso-Muñoz, S.;

González-Sánchez, R.; Siligardi, C.; García-Muiña, F.E. New Circular Networks in Resilient Supply Chains: An External Capital Perspective. Sustainability 2021, 13, 6130. https:// doi.org/10.3390/su13116130

Academic Editor: Idiano D'Adamo

Received: 2 May 2021

Accepted: 27 May 2021

Published: 29 May 2021

Publisher's Note: MDPI stays neutral with regard to jurisdictional claims in published maps and institutional affiliations.

Copyright: (C) 2021 by the authors Licensee MDPI, Basel, Switzerland. This article is an open access article distributed under the terms and conditions of the Creative Commons Attribution (CC BY) license (https:/ / creativecommons.org/licenses/by/ $4.0 /)$.

\begin{abstract}
The pandemic caused by COVID-19 has had an impact on the relationships established between different actors in organisations. To deal with these changes, it is necessary to develop a resilience capacity that allows for the establishment of different patterns of relationships through a new management model. The application of circularity principles implies a radical change in stakeholder relations, breaking with the "end-of-life" concept existing in linear economies. Furthermore, circular economy can ensure resilience in supply chains, and it can be considered as a tool in uncertain environments. Therefore, the objective of this study is to analyse the association between the customer-supplier relationships with circular supply chains based on the intellectual capital-based view theory. External capital is a crucial factor for organisations, and it helps with building remarkable capabilities for the whole supply chain due to collaboration and cooperation. This research contributes with a systematic revision of the literature regarding circular supply chains and customer-supplier external capital, providing an exploratory model. Establishing a closer and effective relationship with customers and suppliers supposes a differentiating value and competitive advantages. Actors involved in the supply chain are essential in the implementation of circularity in organisations for reducing waste production and returning resources to the production cycle. Therefore, circular networks related to customers' behaviour, sustainable supplier election and IT tools play a key factor in improving resilience in supply chains.
\end{abstract}

Keywords: resilient supply chains; external capital; customer-supplier relationship; circular network

\section{Introduction}

The COVID-19 pandemic has had an unprecedented impact on the global industry at all levels around the world [1-3]. Effective crisis management is required in order to restore the confidence between socioeconomic actors. However, beyond the consideration of the negative effects of this type of historical crisis, this new scenario can be a source of opportunities for beneficial change. The concept of resilience is incorporated into the management of organisations to guide this change. "Resilience is the capacity of a system to anticipate, adapt, and reorganize itself under conditions of adversity in ways that promote and sustain its successful functioning" [4] (p. 1).

One of the organisational processes most affected by the current health crisis involves activities related to the supply chain that have been affected by severe ruptures and dysfunctions not experienced in previous pandemics [5-12]. This is because this involves a network of stakeholders and a means of distribution involved in the different global processes and activities. Supply managers have had to deal with a variety of problems such as: (1) mobility restrictions and border closures, (2) shortages of raw materials and workforce, (3) the maintenance of social distance, (4) the radical increase in certain demands for both raw materials and final products and (5) the diversion of certain raw materials for 
the manufacture of products considered to be of greater need to combat COVID-19 [11]. As a result, they have had to adapt quickly to a situation where strategic planning did not anticipate this new scenario. Organisational resilience involves a capacity to adapt to turbulent environments through routines that enable rapid and appropriate responses to change. Thus, the association of resilience and the supply chain has attracted the attention of researchers, although we are still at a basic stage of development.

A resilient supply chain (RSC) enables greater manageability for dealing with disruptions in uncertain business environments, such as the situation caused by COVID-19 [9-12] The severe impact of the COVID-19 pandemic on supply chains leads us to conclude that it is necessary to establish new patterns of relationships in order to solve scenarios in which social distance and mobility restrictions must be maintained [6,10-14].

One of the factors that is attracting the most attention with regard to supply chain management at this stage of the health crisis is related to the new rules that must regulate relations with the different stakeholders [10,11]. Establishing a new framework for more sustainable relationships with suppliers and customers in the postpandemic period would improve value creation. As an example, the automotive industry has relied on global-scale supply chains based on maximum efficiency and just-in-time parts supply, processes that have been blown apart by COVID-19-related restrictions. With a high dependence on components from China, the industry has to diversify its supply chains in order to reduce the risk of stock shortages. However, in the Spanish automotive sector, a significant number of component suppliers are located in the local area of the manufacturers. Therefore, during this crisis, the occasional component shortage was quickly resolved early in the pandemic.

The crisis recovery plan should be based on flexible production strategies involving external and internal resources and capacities. Therefore, achieving a resilient supply chain requires both logistics and relationship network redesign to reduce vulnerability [15]. This study aims to contribute to the establishment of a framework of relationships that will enable the supply chain to be resilient in the face of crises of global impact. Expanding the number of suppliers to cooperate, finding suppliers in proximity to production locations, establishing tools to facilitate communication and involving customers in the return of used products would all contribute to the adaptation to the new business reality [16].

Although many organisations have prioritised survival over investment in other "nonpriority activities" [11], this crisis is an opportunity to consider sustainability as a priority investment in the future as well as a differentiating element. Sustainability is positively related to resilience [17]. The application of sustainability principles to the management and development of the supply chain would make it possible to achieve a more efficient operation with a more engaged ecosystem. It is necessary to incorporate a new framework that regenerates the relationships in the most sustainable way possible. In this way, the application of the principles of circularity would facilitate this transformation [18-20].

The circular economy represents a further step forward in the field of sustainability by breaking with the linear production model with substantial modifications in both operations and relationships [20]. The principles of circularity can provide the supply chain with greater resilience and a more flexible response to future disasters [21]. The functioning of a circular system depends to a high degree on the establishment of well-founded partnerships, mainly with suppliers and customers, which requires the application of a variety of disciplines at different levels [22].

The customer-supplier relationship mechanisms linked with circular economy and supply chains have not been studied enough in the extant literature [23]. To manage this from a resilience perspective, it would be useful to incorporate a theoretical framework to facilitate a developmental model. In this regard, this study is based on the intellectual capital-based view theory (ICV). This theory proposes an efficient management of knowledge through its relationships among external capital, human resources, human capital, organisational design and structural capital. Knowledge management in the supply chain is a topic that is still understudied in the literature, and mainly from a quantitative 
approach [24]. Recent studies highlight the importance of resilient supply chains according to their intellectual capital [13].

In addition, intellectual capital (IC) enables the development of sustainability by generating synergies between stakeholders through novel combinations of their different utilities [25]. Currently, the number of articles about sustainability and intellectual capital has increased, even coining the term "green intangible capital" $[25,26]$, but there is a gap in the research between circular economy and intellectual capital.

External capital is an intangible asset that focuses on the establishment of superior relationships with stakeholders through the alignment of different interests. These stakeholders' interests include concerns about green problems [26]. Through external capital, intellectual capital literature has addressed the study of these aspects and evaluated their strategic potential. Hence, the integration of circular economy and intellectual capital theoretical frameworks can advance developing sustainable and flexibly functioning relationships in turbulent environments.

A resilient supply chain is crucial to financial and economic survival $[9,12,13]$, highlighting the importance of collaborative relationships with customers and suppliers, which could minimise and mitigate disruptions and the negative impacts of the COVID-19 pandemic on supply chains. Our research aims to contribute to the construction of a CI-based theoretical framework that enables the development of circular networks in a resilient supply chain. Specifically, the research questions to be answered are:

1. How does the circular network enable the development of resilience routines in the supply chain based on the intellectual capital-based view theory?

2. How do circular networks in resilient supply chains support sustainability?

This study aims to contribute theoretically to the foundations of resilient supply chains through a systematic literature review. For this purpose, we follow the following structure. After the introduction, the research methodology is presented. In Section 3, the theoretical framework is elaborated. Firstly, the extant literature about the term intellectual capital is explored related to different models, and its three more accepted categories in the current literature are explained. Secondly, the circular economy and circular supply chains concepts are defined, and they are studied with a resilience perspective. In Section 4, the linkage between intellectual capital, particularly external capital, and circularity in supply chains is exposed in a conceptual model, which is developed in Section 5, with seven propositions highlighting the key role of customer-supplier relationships among supply chains towards implementing more circular practices. Finally, in Section 6, conclusions, contributions, limitations, and future research are exposed.

\section{Research Methodology}

The method applied in this study is based on exploratory and conceptual research analysing the link between circular supply chains and external capital. The lack of results obtained in the searches for 'circular economy' or 'circular supply chain' and the concept of 'external capital' have highlighted the gaps to fill in this research.

Systematic reviews are used to synthesise findings in a systematic, reproducible and transparent way [27]. Their use in business research is increasing [28]. This type of review is a research method and process in which the data analysed and collected is assessed and identified. The purpose of a systematic review is to detail and recognise pre-established criteria in the literature to answer the research question suggested. In order to reach reliable results to make decisions and draw conclusions. Qualitative systematic reviews compare results from qualitative studies, compiling articles and assessing quality. The strength of this type of analysis is to study whether an effect is repeated or constant across studies and which studies show this [29].

The information has been extracted from the Web of Science database. The literature review was conducted between January 2021 and April 2021. The search protocol defined is as follows: firstly, the terms were selected, and the keywords were combined using the Boolean operators 'AND' and 'OR' in order to refine the information found. The keywords 
used in the search were: 'circular economy' OR 'circular supply chain' AND 'intellectual capital' AND/OR 'external capital'. Whilst the terms associated were 'suppliers' and 'customers'. Secondly, the results obtained were recorded filtering them by subject and title. Table 1 shows the most researched topics.

Table 1. Most researched topics.

\begin{tabular}{lcc}
\hline \multicolumn{2}{c}{ Topics Researched } & Number of Articles \\
\hline Circular economy/Circular supply chain & Customer relationship & 8 \\
\hline Circular economy/Circular supply chain & Customer behaviour & 31 \\
\hline Circular economy/Circular supply chain & Supplier relationship & 9 \\
\hline Circular economy/Circular supply chain & Supplier behaviour & 7 \\
\hline
\end{tabular}

The total number of articles available for review were 408 . The searches were sorted by journal, selecting the articles that had been published in high impact journals (Journal Citation Report, (JCR) Q1-Q2 and Scimago Journal \& Country Rank, (SJR) Q1, resulting 122 articles). The main journals are the following: Business Strategy and the Environment; Ecological Economics; Environment Development and Sustainability; Journal of Cleaner Production; Journal of Economics \& Management Strategy; Journal of Environmental Management; Journal of Industrial Ecology; Journal of Intellectual Capital; Journal of Knowledge Management; Production Planning \& Control; Renewable \& Sustainable Energy Reviews; Resources, Conservation and Recycling; Sustainability Science; Sustainable Development and Sustainable Production and Consumption. Then, the searches were sorted by author, date of publication, title and abstract reading, excluding 67 articles. The most relevant papers were selected, gathering a core sample of 55 papers, taking into account the purpose of this analysis. In Figure 1, this review process is represented.

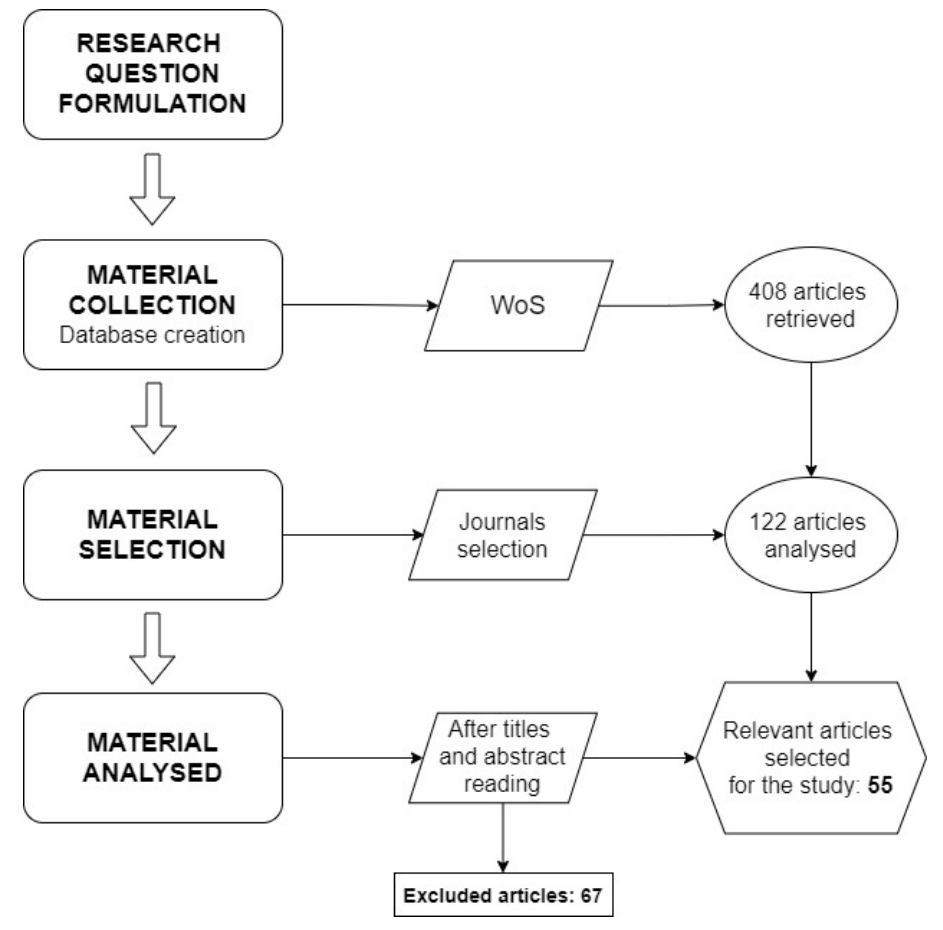

Figure 1. Review process.

Subsequently, once the methodology used in this paper has been explained, the following section will show the theoretical background, conceptualising the main terms studied in this article: resilient supply chain; circular economy and supply chains; and intellectual capital. 


\section{Theoretical Background}

\subsection{Resilient Supply Chain}

Resilience is the capacity for an enterprise to adapt, reorganise its system and keep surviving and growing when a change is undergoing, whilst disturbance is absorbing [30]. RSC implies "the ability of a supply chain to return to normal operating performance, within an acceptable period, after being disturbed" [31] (p.2). The concept of resilience in supply chains refers to mitigating and anticipating disruptions and disturbances throughout adapted techniques for decreasing vulnerabilities in uncertain environments [30].

Operations in the supply chain are constantly under change and conditions of uncertainty; thus, resilience is a key factor. Supply chains must be prepared to respond to unexpected events [32]. Collaboration, supply chain reengineering, agility, innovation, flexibility, visibility, sharing and trust are the main principles for supply chain resilience [31]. Researchers have argued for the importance of some factors for enhancing resilience in supply chains, highlighting integration, cooperation and communication. The capacity to return more quickly to equilibrium after a period of disturbance is called stability [32]. Visibility is also a crucial element of risk reduction in supply chains.

The complexity in supply chain networks demands more resilience. It plays a critical role in the adaptiveness of networks, their interdependencies, their interactions throughout the whole system and their ability to change its behaviour. Designing resilience, collaboration between suppliers and customers, agility and following a risk management culture are general principles for resilience in supply chains networks [30]. Logistics capabilities, such as low-cost distribution, reliability, delivery speed and responsiveness towards dynamic integration, enables resilience in the supply chain for a competitive advantage. Resilience is a requirement in order to achieve sustainable development, and thus a transition to circular networks [32].

\subsection{Circular Economy and Circular Networks}

Environments change rapidly, which is why companies depend on their capabilities to reconfigure, integrate and build their internal and external competencies. Organisations must be able to achieve competitive advantages in innovative ways [33]. Based on this theory, in order to implement new circular models, organisations must rely on their dynamic capabilities. This would enable them to make the transition to more sustainable and circular processes and products, reconfiguring the structure and transforming their relationships in closed-loop chains.

Supply chains can be open or closed loop [34]. Open-loop chains imply that third parties recover materials. Closed-loop chains recover products from customers, returning them to the producer for recovering the value and being able to reuse it as a whole or in part. The aim of both chains is to reuse and recover the value of products and resources, maximising their life cycle and preventing waste by incorporating their return over time [35]. Effective implementation of closed loops depends on the involvement and participation of stakeholders in the supply chain, with the alignment of technical, economic and environmental elements. Relationships with suppliers and customers enable adaptation and resilience to changes in the environment [36].

The circular economy is a restorative and regenerative economic model that breaks with the linear economy, replacing the concept of "end-of-life" by seeking to maintain resources and their value for as long as possible. It seeks to reduce the negative effects on the environment by reducing and eliminating waste [37]. This system aims to minimise the emission and leakage of energy by tightening energy and material loops, following the principle of material balance based on recycling, reuse, refurbishment and remanufacturing [38].

Circular supply chains can bring resources back into the production cycle and reduce waste and residues. The reverse supply chain involves an adaptation of circular economy principles to supply chain management, including product design, activities to maximise value creation and product recovery, among others. In this way, damaged products are 
brought back into operation through the logistics network by means of reconditioning and remanufacturing [39]. Supply chain actors play an essential role in the implementation of the circular economy to promote circular thinking in organisations and rethink the production system, achieving greener and more efficient processes [38]. This circular approach involves expanding the number of partnerships, expanding the number of collaborators and reaching more stable agreements with stakeholders in different industries, mainly suppliers and customers [23]. For this, traditional structures and organisational processes must be renewed with innovations.

\subsection{Conceptualising Intellectual Capital}

The concept of "intellectual capital" was first introduced by Galbraith in 1969, who defined it as an element that produces value for the organisation. A knowledge-based view concerns strategic choice and competitive advantage, taking into account the organizational structure, the nature of coordination and the theory of innovation, and allowing for the renovation of traditional processes and structures in organisations [40]. Thus, intangible resources and assets enable organisations to create value. Intellectual capital (IC) is often synonymous with intangible assets [41]. In this sense, IC is linked to the theory of resources and capabilities, understood as the set of intangible assets and capabilities that a company possesses to generate value to the company. Capabilities lie in processes, and its competitive advantage is based on a collection of skills, complementary assets and routines that are complicated for competitors to imitate.

Sustained competitive advantage depends on the alternatives of competitors to duplicate an organisation's attributes that imply an advantage [42]. Imperfections in transferability imply that resources are not freely transferable and are not available to everyone, because they are heterogeneous and scarce. Competitors cannot imitate valuable organisational resources, which is called "imperfectly imitability". Organisations seek causal ambiguity between their competitive advantages and the resources they possess. Therefore, the advantage is not fully understood by competitors, and for that reason, it is difficult for them to duplicate it.

There is consensus among the three main categories that encompasses intellectual capital: human capital, organisational (or internal) capital and external capital [43].

Human capital is defined as the individual knowledge stock of firms that is represented by workers and their capacity to generate and learn it. According to [44], it can be measured based on training, skills and knowledge.

External capital, also known as relational capital, refers to the network with external stakeholders, such as customers and suppliers, social responsibility activities and customer satisfaction and loyalty [45]. External capital is defined as the values, behavioural rules, codes and common objectives between customers and suppliers that result from collaboration and integration, thanks to an alignment of vision and organisational culture [46].

Establishing a distinctive and nonimitable combination of the resources and capabilities that make up these capitals is a generator of competitive advantages for organisations. The relevance of external capital with the supply chain, highlighting the relationship that organisations have between customers and suppliers, is the main reason for selecting this kind of capital in the current study. This analysis focuses on the role that external capital plays in the adaptive capacity of supply chains, considering the principles of circularity.

\section{Building the Circular Network in the Resilient Supply Chain}

The transition to a sustainability-based approach requires a shared vision among all stakeholders along with a collaborative approach. Manufacturing companies must care more about how to minimise environmental damage, implementing circularity into supply chains and stimulating their innovation, efficiency and cooperation between actors implied by such suppliers and customers [47]. Most studies on supply chain coordination do not take into consideration product quality from an environmental point of view and consumers' environmental concerns [48]. 
Vertical and horizontal cooperation in closed-loop supply chains decreases emissions and costs [49]. Based on the principles of circularity, collaboration networks are established with suppliers and customers on a broad basis, both in terms of number and in terms of the activities involved. This enables the incorporation of new raw materials and new processes and the recovery of end-of-life products into the manufacturing and distribution processes. To this end, connection and trust must be fostered through more active and transparent knowledge and information flows [20].

This requires establishing routines that allow actors to be aware of and take responsibility for the different practices related to technical, social or administrative aspects. External capital is a crucial factor for organisations, and it helps for building remarkable capabilities for the whole supply chain [47].

In terms of external capital, organisations can create competitive advantages by accessing, using and acquiring resources and developing capacities in their supply chains [47]. Regarding supplier-related routines, the focus should be on working towards the establishment of long-term relationships with a large number of suppliers.

\subsection{The Establishment of Knowledge Flows through Supply Chain Intelligence Integraton (SCII)}

Supply chain relationships and interactions strive to improve the environmental collaboration between buyers and suppliers [50]. The implementation of the circular economy requires the approval of all actors in the supply chain [18]. The aim of circularity is to achieve waste reduction and return resources to the production cycle. Coordination and cooperation with suppliers are crucial to supply restorative, recoverable and regenerative raw materials, with less negative effects on the environment [34].

Establishing a closer relationship with customers and suppliers implies a differentiator advantage. External capital in supply chains promotes common actions, and it allows forming stronger relationships. Routines that collect and process information and integrate innovation play a key role to achieve effectiveness and efficiency in external coordination with suppliers and customers. Engineering design choices must be linked, on the one hand, to coordination with suppliers and their components and factories and, on the other hand, to the experience of customers [51]. These dynamic capabilities are necessary to achieve better coordination and cooperation with suppliers and customers, and that is why all agents involved in the supply chain must work in line with each other to succeed in implementing circular models.

External capital implies the accessibility to external knowledge embedded in interorganizational relationships and in networks within suppliers and customers [46]. Good relationships with these external agents improves communication along the supply chain and facilitates the integration of diverse knowledge [52]. In order to leverage the benefits of knowledge incorporated in the supply chain network, organisations must invest in their external capital [46]. Furthermore, external capital and collaboration in supply chains increase the innovation [53] and process redesign, a key element for implementing circular practices, promoting interdependence of resources, information and communication between the companies and parties engaged. In a transaction, trust is the ability to believe and trust the other party, which is crucial for purchase intention [54]. So-called "green trust" involves consumers' confidence that it will be an environmentally sustainable product. To achieve this, it is essential to establish two-way knowledge flows between the organisation and the stakeholders involved in the supply and distribution process [20].

Organisations enhance their collaboration and relationships with supply chain partners, suppliers and customers when they possess valuable knowledge resources. The longterm partnership that takes place with supply chain agents is based on the exchange of knowledge, resources and information through fluid communication between the parties. Shared values and culture, satisfaction, commitment, trust, coordination and collaboration are key points [55].

External capital plays a key role in achieving transparency in the relationship between actors implied in the supply chain [56]. Transparency provides information about the 
interaction and relationship of both parties that can create value and enhance competitive advantage, commitment and satisfaction between the agents. Cooperation along the supply chain enhances partnerships [57]. The relationship between supply chain actors is called partnership and follows transparency, as it involves a close long-term relationship with open communication, mutual coordination of efforts and joint planification [58].

Suppliers and customers' knowledge are crucial as external sources in addition to applying internal knowledge to conduct innovation practices in organisations [59]. The knowledge obtained from suppliers and customers could improve a firm's customer satisfaction and operational and green performance [60]. The knowledge embedded in supply chain networks is called supply chain intelligence (SCI), whilst the application and absorption of knowledge from supply chain collaborators is a process denoted as supply chain intelligence integration (SCII) [61]. SCII integrates knowledge application from organisations and knowledge absorption by supply chain partners [40]. External capital supports SCII knowledge processing [62], which is crucial for an organisation's innovation practices. Supplier intelligence integration promotes a more efficient application and a rapid absorption of knowledge from suppliers, which helps to adjust productivity when environments change quickly [63]. Likewise, customer intelligence integration analyses a greater understanding of customer demands, needs and expectation from the market [59].

Consequently, we postulate that:

Proposition 1 (P1). Supply chain intelligence integration (SCII) positively affects circular networks in resilient supply chains by supporting and sharing knowledge between suppliers and customers.

\subsection{The Establishment of Greener Logistics and Intelligent Transport through Industry 4.0}

In terms of pollution, suppliers have a high environmental impact, which is why cooperation and coordination with them is necessary to achieve a greener product [64]. Organisations have the option to select suppliers with environmental and social standards and who have implemented so-called "reverse logistics" based on remanufacturing and waste management. This is key to the development of reverse logistics, the consideration of waste and how it is managed [23]. In reverse logistics, resources that have become obsolete are moved between companies in order to provide for their favourable disposal or to recapture their value [65]. The right choice of suppliers can boost material circularity and reduce environmental damage [64].

Industry 4.0 plays an essential role in sustainability in organisations, highlighting the improvement of logistics and intelligent transport management. It could have an impact on promoting greater monitoring of sustainable principles, "green" consumer behaviour, increasing product visibility throughout its life cycle and decreasing operational and development costs [66]. Industry 4.0 encompasses artificial intelligence, 5G networking, the Internet of things (IoT), robotics, blockchain, augmented reality and 3D printing, among others [67]. Currently, there are numerous programmes to make logistics management greener through distributed manufacturing systems and self-driving vehicles [68]. Furthermore, external capital can be related to the right information and communications technology (ICT) management, and R\&D investments are influenced by industry 4.0 [69]. As [66] point out in their study, Industry 4.0 makes the exchange of knowledge and information along the supply chain more transparent and improves decision making between different parties. Digital technologies offer opportunities to integrate and implement the circular economy in supply chains [66]. Consequently, we postulate that:

Proposition 2 (P2). Industry 4.0 positively affects circular networks in resilient supply chains by achieving greener logistics and intelligent transport. 


\subsection{The Optimisation of the Supplier Selection Process through Ethical Codes and Multicriteria Tools}

The composition of certain products supposes that when discarded at the end of their lifespan, they are major pollutants that harm human health, which is why environmental collaboration in the supply chain is important. The most crucial elements for a more circular supply chain are low carbon emissions, sustainability, and green suppliers [70]. The selection of suppliers affects the behaviour of environmentally responsible organisations [71].

Suppliers should be selected on the basis of their sustainable or green performance, taking into account aspects such as sustainable product packaging, use of renewable energy, recycled items and reduction of emissions associated with manufacturing and transportation [72]. To optimise the supply chain network, it is important to detail the most efficient location of facilities and the necessary connections in order to reduce carbon emissions and associated costs [73]. Reducing transport and promoting local supplier relationships is one of the recommendations to implement more circular practices [74]. Recent practical examples support this trend. Permanent magnets, a component used in various technological products such as mobile phones and cars, are made from rare earth that is mined in developing countries without any environmental safeguards. In the circular current, the use of recycled raw materials and a manufacturing change of raw materials are being encouraged, and consequently, a search for more environmentally friendly suppliers available in nearby markets is also being encouraged. These sustainable practices by suppliers are recognised through environmental certifications, such as ISO 14000, which allow the most ecoefficient suppliers to be identified [74]. The circular economy encompasses new ethical relationships and moral requirements throughout the supply chain, according to the sustainable and circular value principles. New production methods were initiated based on ethical codes and attitudes which respect the environment. This requires a circular economy development model to establish new production ethical codes guidelines, such as emission reductions, cleaner production and resource conservation, integrating long-term interests within suppliers [75,76].

It is therefore recommended that ethical codes be established for the selection of suppliers, setting out the principles and features they must comply with in order to be part of the network.

Supply chain partnerships have improved due to globalisation and computerisation [70]. A better supplier selection can be achieved using IT tools such as big data or data mining to study the environmental impact of suppliers. Several green supplier ranking tools exist, such as the linguistic entropy weighting method, LEWM, which evaluates the different possibilities. The authors of [77] conducted a study in which they take into account environmental issues to put pressure on actors involved in supply chains. Multicriteria decision-making approaches, MCDM, are used to select suppliers through evaluation [74], and another method of note is the analytic hierarchy process, AHP [78]. Ecodesign capabilities, compliance with legislation, codification, pollution control, green competencies, product recycling, environmental efficiency, use of clean energy and materials and green image, among others, are the main selection criteria [74].

Thus, the following is being proposed:

Proposition 3 (P3). Ethical codes and multicriteria tools positively affect circular networks in resilient supply chains by improving the supplier selection process.

\subsection{The Establishment of a Strong Relationship Based on Supplier's Trust and Commitment}

One of the most important criteria when engaging with a supplier is to establish an appropriate level of commitment [77]. Sustainable and circular supply chain practices and collaboration within the supply chain are facilitated by suppliers' trust in the organisations they engage with [79]. Trust is a good mechanism for organisational control and for improving supply chain performance and fostering interfirm relationships [80]. 
Supplier trust, information and knowledge sharing and collaboration and communication are key aspects of supplier relationships. Providing support, motivation, training, assistance and active participation by allowing suggestions or feedback gives suppliers confidence in organisations. In addition, reward mechanisms have a positive effect on engagement [79].

Proposition 4 (P4). Assistance, active participation and reward mechanisms positively affect circular networks in resilient supply chains by improving the suppliers' commitment.

\subsection{The Establishment of Customer Acceptance through Warranty Policies, Additional Services and New Service-Oriented Contracts}

Collaborating with consumers in process and product innovation is essential for companies for applying new knowledge and customers' preferences that are changing rapidly [81]. Companies can be more adaptative to the changes because of the supplier and customer partnership and the transferring of knowledge [82]. This implies a key factor towards circularity, e.g., in terms of customer's green behaviour, for recycling or remanufacturing. Repair extends the lifespan of many products, which can be designed to have a long service life or can be extended through repair, refurbishment and remanufacturing. Furthermore, through recycling it is possible to close the loop [83].

Market acceptance of remanufacturing is low as consumers think of lower quality products; when customers understand that remanufactured products use less energy, are less resource intensive and have ecological benefits, customer acceptability will increase [84]. Experience and satisfaction with previous purchases also play an important role [85]. The marketing of remanufactured products implies a challenge for organisations, highlighting the low incentives to buy remanufactured products [86].

Refurbishment is an environmentally beneficial strategy that contributes to the circular economy by bringing back used products and repairing or replacing components [87]. The concept of refurbishment is often unclear to consumers, and the lack of attractiveness of these products and their unavailability in all markets are the main barriers [88].

It is important to provide information to raise consumer awareness; the use or purchase of remanufactured products can be encouraged through new ways of consuming a product based on use rather than purchase, complementarity through additional services or by extending the warranty against malfunctions $[88,89]$. Product price is affected by warranty duration and reliability and plays a determining role in the efficiency and profit of the supply chain. The performance of the closed-loop supply chain is affected by the warranty period, which in turn fixes the reliability of products and perceived value [90]. A strong relationship with customers is imperative to engage in reuse, recycling and take-back activities and to incorporate new business models such as collaborative consumption [91]. The leasing contract allows the customer to use an asset in exchange for the payment of lease rentals with the option to buy the leased asset, return it or renew the contract.

Hence, we formulate:

Proposition 5 (P5). Warranty policies, additional services and new service-oriented contracts positively affect circular networks in resilient supply chains by increasing customer acceptability of remanufactured or refurbished products.

4.6. The Establishment of Customer Participation and Purchase Promotion through Enviromental Education, Rewards and Discounts

Product-service systems (PSS) enable resource recovery, reuse, and recycling. Several studies report how circularity influences consumer behaviour by changing their role to a more active one in closed-loop systems [92]. Effectively collected resources can be used again in their life cycle; at this point, consumers play a crucial role, because the quality of revalued goods is improved by the key activities of separation, sorting, storage, collection and disposal [93]. In the linear economy, consumers were the last link in the supply chain, 
playing a passive role, but in the circular economy they are actively involved in the recovery and recycling of products and waste [94].

Customers can follow more sustainable purchasing behaviours by purchasing products that are less harmful to the environment, thus lowering environmental and social impacts [95]. Raising awareness of circular consumption through policies is imperative [23]. Consumers are key stakeholders in the return of products when they become obsolete and determine the success of circular systems [96].

Encouraging consumer proactivity and efforts to reflect green thinking in their consumption patterns is critical to the successful implementation of circular relationships [97]. Through environmental education campaigns or programmes, customers can understand the importance of sustainable purchasing behaviour [98]. It is important to make consumers aware of the quality and environmental impact of the products they buy by providing them with additional information. Translating environmental data into understandable information influences sustainable consumption [99].

Consumer awareness is defined as the level of consumer awareness of their responsibility towards the environment and of information about the alternatives they have in the market. However, there are barriers that can interfere with the positive effect that awareness has on changes in consumer behaviour. For example, there may be a lack of alternatives or price increases for ecoresponsible products [100].

Individual consumer behaviour can be measured and predicted based on their purchase intention, according to the theory of reasoned action (TRA), although factors can change attitudes and interfere [101]. The company should look for factors that encourage consumers to buy or participate in certain circular processes. These tools would facilitate processes such as the establishment of rewards or discounts.

To improve purchasing behaviour, organisations could apply financial rewards or discounts on future purchases to motivate consumers to participate, for example, in sending their products to collection or recycling points, among other measures [98]. On-site collection services and exchange of used products for a reduction in the purchase price of new products are other incentive measures that circular organisations can use in the development of their external capital [102]. It is necessary for companies to explore the incentives they can use with their consumers to change their purchase intention and their motivations to participate in product returns [103].

The willingness to pay a higher price for a product that has been produced in a more environmentally friendly way is a critical point to address. However, by raising consumer awareness, consumers can be made willing to pay more for a product produced in a more ecoefficient way, which reduces the environmental and social impact [95]. In order to make consumers willing to pay a higher price for a product resulting from the implementation of a circular system, an awareness or educational process is required. However, in the early stages of developing environmental awareness, it is key that green products are priced competitively in order to be attractive [104]. Some studies [105] argue that the higher the discounts are for returning used products, the more effect on customers' decisions.

According to the literature, we can postulate that:

Proposition 6 (P6). Environmental education, rewards and discounts positively affect circular networks in resilient supply chains by increasing customer purchase promotion and participation in product recovery processes.

\section{Designing a Conceptual Model}

This section illustrates the design of the conceptual model where the links between the elements studied are identified. The model proposed seeks to fill the gap in the literature by taking into account the importance between the key role of customer-supplier relationships in order to implement more circular and resilient supply chains.

Six main propositions have been suggested. The first (P1) outlined that supply chain intelligence integration (SCII) positively affects circular networks in resilient supply chains 
by supporting and sharing knowledge between suppliers and customers. The second proposition (P2) argues that Industry 4.0 positively affects circular networks in resilient supply chains by achieving greener logistics and intelligent transport. The third proposition (P3) notes that ethical codes and multicriteria tools positively affect circular networks in resilient supply chains by improving the supplier selection process. The fourth proposition (P4) indicates that assistance, active participation and reward mechanisms positively affect circular networks in resilient supply chains by improving the suppliers' commitment.

The fifth proposition (P5) highlights that warranty policies, additional services and new service-oriented contracts positively affect circular networks in resilient supply chains by increasing customer acceptability with remanufactured or refurbished products. Finally, the sixth proposition (P6) states that environmental education, rewards and discounts positively affect circular networks in resilient supply chains by increasing customer purchase promotion and participation in product recovery processes.

The conceptual model (Figure 2) offers an overview on the connections among the topics studied and their linkage between the customer-supplier relationship and circular supply chains. The model demonstrates the connection between external capital and circularity in order to achieve more resilience in supply chains. Transparency plays a key role in providing information about the interactions. Relationships with suppliers and customers imply the access to the external knowledge embedded, SCII [61]. SCII supposes a rapid absorption of knowledge from suppliers and a better understanding of customers' needs, highlighting the importance of an appropriate level of commitment with suppliers and taking into account that motivation, support, assistance and training improve confidence in organisations.

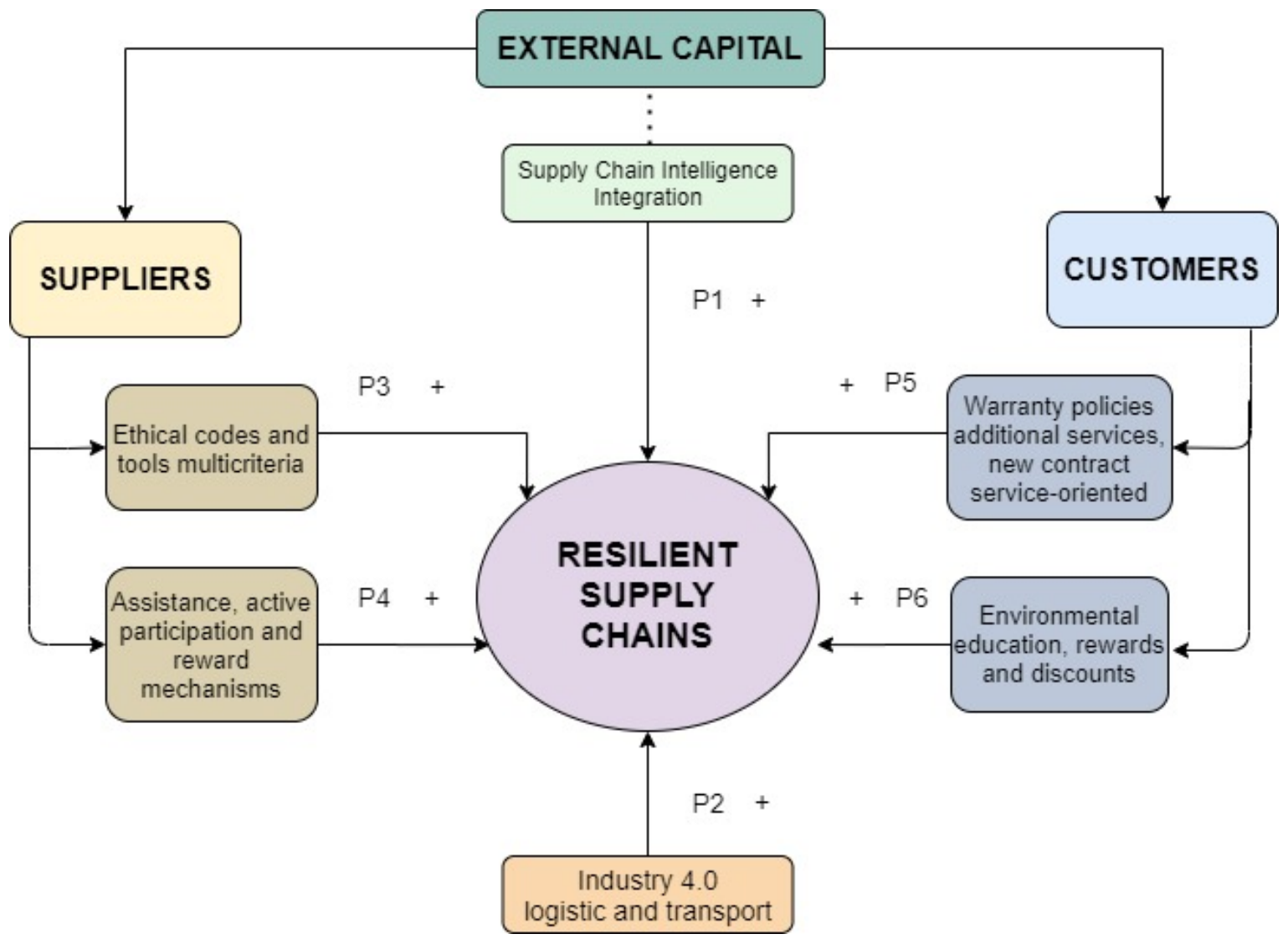

Figure 2. Conceptual model.

Organisations must select those suppliers with environmental concerns and those that develop reverse logistics. The implementation of logistics and intelligent transport management is possible thanks to Industry 4.0, which makes the exchange of knowledge and 
information throughout the supply chain more transparent between parties. For instance, multicriteria tools such as MCDM or AHP resulted in a greater supplier's selection [74,78].

On the other hand, providing information to raise consumer awareness is key. Warranty periods and leasing options increase customer acceptability with refurbished and remanufactured products $[89,106]$. Applying financial rewards or discounts on future purchases motivates customers to return used products according to circularity practices. Furthermore, educational environment campaigns encourage customers to participate actively in product recovery [107].

\section{Conclusions}

The COVID-19 pandemic has affected the functioning of supply chains in a way never seen before [11]. This has meant the disruption of organisational operations due to a lack of supply and mobility problems that have prevented the development of transport for a prolonged period. Organisations need to be resilient and adapt the functioning of their networks $[3,36]$. Many sectors are moving towards sustainable practices achieving resilience, such as automotive production and the technology components industry. Sustainability is an element that could build resilience, and both concepts pursue sustainable development [108].

The implementation of sustainable strategies can facilitate such changes, as it can have economic, social and environmental benefits. Therefore, applying the principles of circularity is a step forward on the road to sustainability for organisations. The circular economy is a revolution at a relational, production and technological level. This implies the establishment of new knowledge flows, which requires the establishment of routines and tools to facilitate them [20].

Based on the intellectual capital-based view theory (ICV), this study aims to provide an operational framework for the circular relationships that are established in circular supply chains. In particular, the external capital that facilitates and optimises knowledge flows with actors outside the organisation has been analysed [24]. Applying the principles of circularity to the supply chain allows new rules to be established with suppliers and customers. It increases the number of actors with an active role in greener operations. A long-term partnership between customers and suppliers is fundamental to achieve social and environmental solutions [109]. The design of new networks in supply chains needs to be further analysed to achieve resilience, effectiveness and efficiency through circularity [18].

The contributions in this article can be differentiated between theoretical and practical contributions.

\subsection{Theoretical Contribution}

Several current studies, mainly empirical, focus on the productive and technological aspects of the circular economy. Throughout this paper, we aim to contribute to the construction of a theoretical basis that focuses on the management of circular network relationships. Intellectual capital-based view theory (ICV) provides us a framework for action that favours knowledge flows in supply chain relationships [24]. We therefore focus on external capital. Although there is literature linking external capital to sustainability, there is a significant gap in the relationship between external capital and circularity.

Even though this conceptual model is exploratory, what is developed in this research provides theoretical contributions to the circular supply chain the literature, thanks to the linkage presented between customer-supplier relationships and circularity, filling this gap in the literature.

\subsection{Practical Contribution}

External capital proposes the establishment of routines and tools that facilitate the flow of knowledge from actors outside the organisation. In this sense, our study postulates the use of this framework in order to favour relations with suppliers and customers 
under the principles of circularity [47,51]. Organisations must take advantage of the necessary investments and organisational changes that must be made to adapt to the new postpandemic scenario to make a real commitment to sustainability [47].

It is essential to establish a climate of trust with both suppliers and customers. The development of training and information programs in the target markets modifies the behaviour and consumption patterns of customers by considering the principles of sustainability [79]. However, the effects of these programs are not immediate, so complementary tools must be put in place to build customer confidence.

To this end, the use of specific guarantees and the offer of complementary services are proposed. In addition, companies must adapt to new consumption patterns that focus on use rather than possession. Therefore, the offer of companies must be adapted to this. Accompanying a new offer, the use of discounts would also allow the customer to buy or carry out circular activities [105].

To build trust with suppliers, activities are proposed to enable the organisation to maintain a closer relationship with them. Through a reward system, if certain standards are met and advisory and support services are established, suppliers will be more likely to adopt circularity principles in their value chain $[79,107]$. In addition, the establishment of ethical codes and supplier selection systems through multicriteria tools will help to ensure that suppliers are more likely to adopt circularity principles in their value chain $[75,76]$.

\subsection{Limitation and Future Recommendation}

In the literature review, we have found a majority of papers that consider intangible capital with sustainability. This shows that it is still a developing field of research. Our research has focused on the application of external capital, given the importance of relationships in supply chain development, with much of the research focused on the operational and technological part of the process [110]. However, in future research, it would be interesting to study the joint effect of the three types of intellectual capital. Similarly, their practical application in different sectors would allow us to establish useful empirical evidence to adapt or extend the proposal offered.

Author Contributions: Conceptualization, R.G.-S. and S.A.-M.; methodology C.S. and F.E.G.-M.; investigation, C.S. and F.E.G.-M.; writing-original draft preparation, R.G.-S. and S.A.-M.; writingreview and editing, C.S. and F.E.G.-M.; supervision, R.G.-S. and F.E.G.-M. All authors have read and agreed to the published version of the manuscript.

Funding: This research was funded by the European Union under the LIFE Program, grant number: LIFE16ENV/IT/000307 (LIFE Force of the Future).

Institutional Review Board Statement: Not applicable.

Informed Consent Statement: Not applicable.

Data Availability Statement: Not applicable.

Conflicts of Interest: The authors declare no conflict of interest.

\section{References}

1. Zenker, S.; Kock, F. The coronavirus pandemic-A critical discussion of a tourism research agenda. Tour. Manag. 2020, 81, 104164. [CrossRef]

2. Giudice, F.; Caferra, R.; Morone, P. COVID-19, the food system and the circular economy: Challenges and opportunities. Sustainability 2020, 12, 7939. [CrossRef]

3. Siagian, H.; Tarigan, Z.J.H.; Jie, F. Supply chain integration enables resilience, flexibility, and innovation to improve business performance in COVID-19 era. Sustainability 2021, 13, 4669. [CrossRef]

4. Ungar, M. Systematic resilience: Principles and processes for a science of change in contexts of adversity. Ecol. Soc. 2018, 23, 34. [CrossRef]

5. Singh, S.; Kumar, R.; Panchal, R.; Tiwari, M.K. Impact of COVID-19 on logistics systems and disruptions in food supply chain. Int. J. Prod. Res. 2021, 59, 1993-2008. [CrossRef]

6. Golan, M.S.; Jernegan, L.H.; Linkov, I. Trends and applications of resilience analytics in supply chain modeling: Systematic literature review in the context of the COVID-19 pandemic. Environ. Syst. Decis. 2020, 1. [CrossRef] [PubMed] 
7. Remko, V.H. Research opportunities for a more resilient post-COVID-19 supply chain-Closing the gap between research findings and industry practice. Int. J. Oper. Prod. Manag. 2020, 40, 341-355. [CrossRef]

8. Govindan, K.; Mina, H.; Alavi, B. A decision support system for demand management in healthcare supply chains considering the epidemic outbreaks: A case study of coronavirus disease 2019 (COVID-19). Transp. Res. Part. E Logist. Transp. Rev. 2020, 138, 101967. [CrossRef]

9. Farooq, M.U.; Hussain, A.; Masood, T.; Habib, M.S. Supply chain operations management in pandemics: A state-of-the-art revire inspired by COVID-19. Sustainability 2021, 13, 2504. [CrossRef]

10. Chowdhury, T.; Sarkar, A.; Sanjoy, K.P.; Moktadir, A. A case study on strategies to deal with the impacts of COVID-19 pandemic in the food and beverage industry. Oper. Manag. Res. 2020. [CrossRef]

11. Chowdhury, P.; Sanjoy, K.P.; Kaisar, S.; Moktadir, A. COVID-19 pandemic related supply chain studies: A systematic review. Transp. Res. Part E 2021, 148, 102271. [CrossRef]

12. Paul, S.K.; Chowdhury, P. A production recovery plan in manufacturing supply chains for a high-demand item during COVID-19. Int. J. Phys. Distrib. Logist. Manag. 2021, 51, 104-125. [CrossRef]

13. Mubarik, M.S.; Bontis, N.; Mubarik, M.; Mahmood, T. Intellectual capital and supply chain resilience. J. Intellect. Cap. 2021, 1469-1930. [CrossRef]

14. Centobelli, P.; Cerchione, R.; Ertz, M. Managing supply chain resilience to pursue business and environmental strategies. Bus. Strategy Environ. 2020, 29, 1215-1246. [CrossRef]

15. Queiroz, M.M.; Ivanov, D.; Dolgui, A.; Wamba, S.F. Impacts of epidemic outbreaks on supply chains: Mapping a re-search agenda amid the COVID-19 pandemic through a structured literature review. Ann. Oper. Res. 2020. [CrossRef] [PubMed]

16. Sharma, G.; Volgman, A.S.; Michos, E.D. Sex differences in mortality from COVID-19 pandemic: Are men vulnerable and women protected? Case Rep. 2020, 2, 1407-1410.

17. D'Adamo, I.; Rosa, P. How do you see infraestructure? Green energy to provide economic growth after COVID-19. Sustainability 2020, 12, 4738. [CrossRef]

18. Muñoz-Torres, M.J.; Fernández-Izquierdo, M.A.; Rivera-Lirio, J.M.; Ferrero-Ferrero, I.; Escrig-Olmedo, E. An Assessment Tool to Integrate Sustainability Principles into the Global Supply Chain. Sustainability 2018, 10, 535. [CrossRef]

19. D'Adamo, I.; Lupi, G. Sustainability and resilience after COVID-19: A circular premium in the fashion industry. Sustainability 2021, 13, 1861. [CrossRef]

20. Alonso-Muñoz, S.; González-Sánchez, R.; Siligardi, C.; García-Muiña, F.E. Building exploitation routines in the circular supply chain to obtain radical innovations. Resources 2021, 10, 22. [CrossRef]

21. Choi, T.Y.; Roger, D.; Vakil, B. Coronavirus Is a Wake-Up Call for Supply Chain Management. 2020. Available online: https: / /hbr.org/2020/03/coronavirus-is-awake-up-call-for-supply-chain-management (accessed on 10 February 2021).

22. Brown, P.; von Daniels, C.; Bocken, N.M.P.; Balkenende, A.R. A process model for collaboration in circular oriented innovation. J. Clean. Prod. 2021, 286, 125499. [CrossRef]

23. Farooque, M.; Zhang, A.; Thürer, M.S.; Qu, T.; Huisingh, D. Circular supply chain management: A definition and structured literature review. J. Clean. Prod. 2019, 228, 882-900. [CrossRef]

24. Cerchione, R.; Esposito, E. A systematic review of supply chain knowledge management research: State of the art and research opportunities. Int. J. Prod. Econ. 2016, 182, 276-292. [CrossRef]

25. Minoja, M.; Romano, G. Managing intelectual capital for sustainability: Evidence from a remunicipalized, publicly owned waste management firm. J. Clean. Prod. 2021, 279, 123213. [CrossRef]

26. Yong, J.Y.; Yusliza, M.Y.; Ramayah, T.; Fawehinmi, O. Nexus between green intellectual capital and green human resource management. J. Clean. Prod. 2019, 215, 364-374. [CrossRef]

27. Davis, J.; Mengersen, K.; Bennett, S.; Mazerolle, L. Viewing systematic reviews and meta-analysis in social research through different lenses. Springer Plus 2014, 3, 511. [CrossRef]

28. Snyder, H.; Witell, L.; Gustafsson, A.; Fombelle, P.; Kristensson, P. Identifying categories of service innovation: A review and synthesis of the literature. J. Bus. Res. 2016, 69, 2401-2408. [CrossRef]

29. Snyder, H. Literature review as a research methodology: An overview and guidelines. J. Bus. Res. 2019, 104, 333-339. [CrossRef]

30. Souza, V.; Bloemhof-Ruwaard, J.; Borsato, M. Towards Regenerative Supply Networks: A design framework proposal. J. Clean. Prod. 2019, 221, 145-156. [CrossRef]

31. Christopher, M.; Peck, H.; Rutherford, C.; Juttner, U. Supply Chain Resilience, Cranfield Centre for Logistics and Supply Chain Management. Cranfield Sch. Manag. 2003. Available online: https://www.cranfield.ac.uk/som/masters-courses/logistics-andsupply-chain-management (accessed on 10 February 2021).

32. Serhiy, Y.; Ponomarov, M.; Holcomb, C. Understanding the concept of supply chain resilience. Int. J. Logist. Manag. 2009, 20, 124-143. [CrossRef]

33. Teece, D.J.; Pisano, G.; Shuen, A. Dynamic capabilities and strategic management. Strategy Manag. J. 1997, 18, 509-533. [CrossRef]

34. Genovese, A.; Acquaye, A.A.; Figueroa, A.; Koh, S.L. Sustainable supply chain management and the transition towards a circular economy: Evidence and some applications. Omega 2017, 66, 344-357. [CrossRef]

35. Yang, M.; Smart, P.; Kumar, M.; Jolly, M.; Evans, S. Product-service systems business models for circular supply chains. Prod. Plan. Control 2018, 29, 498-508. [CrossRef]

36. Borgatti, S.P.; Li, X. On social network analysis in a supply chain context. J. Supply Chain Manag. 2009, 45, 5-22. [CrossRef] 
37. Charonis, G. Degrowth, Steady State Economics and the Circular Economy: Three Distinct yet Increasingly Converging Alternative Discourses to Economic Growth for Achieving Environmental Sustainability and Social Equity. World Economic Association Sustainability Conference. 2012. Available online: https://sustainabilityconference2012.weaconferences.net/ papers / degrowth-steady-state-economics-and-the-circular-economy-three-distinct-yet-increasingly-converging-alternativediscourses-to-economic-growth-for-achieving-environmental-sustainability-and-social-eq/ (accessed on 4 February 2021).

38. Geissdoerfer, M.; Savaget, P.M.P.; Bocken, N.; Hultink, E.J. The circular economy: A new sustainability paradigm? J. Clean. Prod. 2017, 143, 757-768. [CrossRef]

39. Cui, Y.Y.; Guan, Z.; Saif, U.; Zhang, L.; Zhang, F.; Mirza, J. Close Loop Supply Chain Network Problem with Uncertainty in Demand and Returned Products: Genetic Artificial Bee Colony Algorithm Approach. J. Clean. Prod. 2017, 162, 717-742. [CrossRef]

40. Grant, R.M. A resource based theory of competitive advantage. Calif. Manag. Rev. 1991, 3, 114-135. [CrossRef]

41. Brooking, A. Intellectual Capital: Core Asset for the Third Millennium Enterprise; Thomson Business Press: London, UK, 1997.

42. Barney, J.B. Firm resources and sustained competitive advantage. J. Manag. 1991, 17, 99-120. [CrossRef]

43. Daou, A.; Joseph, J.; Yousif, D.S.; Fathallah, R.; Reyes, G. Intellectual capital and resilience in torn societies. J. Intellect. Cap. 2019, 20, 598-618. [CrossRef]

44. Bontis, N. World Congress on Intellectual Capital Reading; Butterworth-Heinemann: Boston, MA, USA, 2002.

45. Alipour, M. The effect of intellectual capital on firm performance: An investigation of Iran insurance companies. Meas. Bus. Excell. 2012, 16, 53-66. [CrossRef]

46. Shou, Y.; Hu, W.; Xu, Y. Exploring the role of intellectual capital in supply chain intelligence integration. Ind. Manag. Data Syst. 2018, 118. [CrossRef]

47. Wu, R.; Huo, B.; Yu, Y.; Zhang, Z. Quality and green management for operational and environmental performance: Relational capital in supply chain management. Int. J. Logist. Res. Appl. 2020. [CrossRef]

48. Zhang, W.; He, Y. Optimal policies for new and green remanufactured shortlife-cycle products considering consumer behavior. J. Clean. Prod. 2019, 214, 483-505. [CrossRef]

49. Li, W.; Chen, J.; Chen, B. Supply chain coordination with customer returns and retailer's store brand product. Int. J. Prod. Econ. 2018, 203, 69-82. [CrossRef]

50. Woo, C.; Kim, M.G.; Chung, Y.; Rho, J.J. Suppliers' communication capability and external green integration for green and financial performance in Korean construction industry. J. Clean. Prod. 2016, 112, 483-493. [CrossRef]

51. Garvin, D.A. The Processes of Organization and Management. MIT Sloan Manag. Rev. 1998. Available online: https://sloanreview. mit.edu/article/the-processes-of-organization-and-management/ (accessed on 28 February 2021).

52. Acedo, F.J.; Barroso, C.; Galan, J.L. The resource-based theory: Dissemination and main trends. Strategy Manag. J. 2006, 27, 621-636. [CrossRef]

53. Anh, N.T.M.; Hui, L.; Khoa, V.D.; Mehmood, S. Relational capital and supply chain collaboration for radical and incremental innovation: An empirical study in China. Asia Pac. J. Mark. Logist. 2019, 31, 1076-1094. [CrossRef]

54. Moorman, C.; Deshpande, R.; Zaltman, G. Factors affecting trust in market research relationships. J. Mark. 1993, 57, 81-101. [CrossRef]

55. Boddy, D.M.; Wagner, B. Implementing collaboration between organizations: An empirical study of supply chain partnering. J. Manag. Stud. 2000, 37, 1003-1018. [CrossRef]

56. Kang, S.C.; Snell, S.A. Intellectual capital architectures and ambidextrous learning-A framework for human resource management. J. Manag. Stud. 2009, 46, 65-92. [CrossRef]

57. Eggert, A.; Helm, S. Exploring the impact of relationship transparency on business relationships: A crosssectional study among purchasing managers in Germany. Ind. Mark. Manag. 2003, 32, 101-108. [CrossRef]

58. Tuten, T.; Urban, D. An expanded model of business-to-business partnership formation and success. Ind. Mark. Manag. 2001, 30, 149-164. [CrossRef]

59. Carbonell, P.; Rodríguez-Escudero, A.I.; Pujari, D. Customer involvement in new service development: An examination of antecedents and outcomes. J. Prod. Innov. Manag. 2009, 26, 536-550. [CrossRef]

60. Du, L.; Zhang, Z.; Feng, T. Linking green customer and supplier integration with green innovation performance: The role of internal integration. Bus. Strategy Environ. 2018, 27, 1583-1595. [CrossRef]

61. Schoenherr, T.; Swink, M. The roles of supply chain intelligence and adaptability in new product launch success. Decis. Sci. 2015, 46, 901-936. [CrossRef]

62. Jones, O.; Macpherson, A. Inter-organizational learning and strategic renewal in SMEs: Extending the 4I framework. Long Range Plan. 2006, 39, 155-175. [CrossRef]

63. Wowak, K.D.; Craighead, C.W.; Ketchen, D.J.; Hult, G.T.M. Supply chain knowledge and performance: A meta-analysis. Decis. Sci. 2013, 44, 843-875. [CrossRef]

64. Govindan, K.; Mina, H.; Esmaeili, A.; Gholami-Zanjani, S.M. An Integrated Hybrid Approach for Circular supplier selection and Closed loop Supply Chain Network Design under Uncertainty. J. Clean. Prod. 2020, 242. [CrossRef]

65. Souza, G.C. Closed-loop supply chains: A critical review, and future research. Decis. Sci. J. 2013, 44, 7-38. [CrossRef]

66. Esmaeiliana, B.; Sarkis, J.; Lewis, K.; Behdad, S. Blockchain for the future of sustainable supply chain management in Industry 4.0. Resour. Conserv. Recycl. 2020, 163, 105064. [CrossRef] 
67. Rayome, A.D. Top 10 Emerging Technologies of 2019. TechRepublic 2019. Available online: https://www.techrepublic.com/ article/top-10-emerging-technologies-of-2019/ (accessed on 3 March 2021).

68. Prause, G. Sustainable business models and structures for Industry 4.0. J. Secur. Sustain. Issues 2015, 5. [CrossRef]

69. Davenport, T.H.; Prusak, L. Working Knowledge: How Organizations Manage What They Know; Harvard Business School Press: Boston, MA, USA, 1997. [CrossRef]

70. Feng, H.J.; Gong, Z. Integrated linguistic entropy weight method and multi-objective programming model for supplier selection and order allocation in a circular economy: A case study. J. Clean. Prod. 2020, 277, 122597. [CrossRef]

71. Zou, Z.; Wang, J.; Deng, G.; Chen, H. Third-party remanufacturing mode selection: Outsourcing or authorization? Transport. Res. E Logist. Transport. Rev. 2016, 87, 1-19. [CrossRef]

72. Yu, Y.; Zhang, M.; Huo, B. The impact of relational capital on green supply chain management and financial performance. Prod. Plan. Control 2020. [CrossRef]

73. Zohal, M.; Soleimani, H. Developing an ant colony approach for green closed-loop supply chain network design: A case study in gold industry. J. Clean. Prod. 2016, 133, 314-337. [CrossRef]

74. Kannan, D.; Khodaverdi, R.; Olfat, L.; Jafarian, A.; Diabat, A. Integrated fuzzy multi criteria decision making method and multi-objective programming approach for supplier selection and order allocation in a green supply chain. J. Clean. Prod. 2013, 47, 355-367. [CrossRef]

75. Qiao, F.; Qiao, N. Circular economy: An ethical and sustainable economic development model. Prakseologia 2013, 154, $253-272$.

76. Salvioni, D.M.; Astori, R.; Cassano, R. Corporate sustainability and ethical codes effectiveness. J. Mod. Acc. Audit. 2014, 10, 969-982. [CrossRef]

77. Mishra, A.R.; Rani, P.; Pardasani, K.R.; Mardani, A. A novel hesitant fuzzy WASPAS method for assessment of green supplier problem based on exponential information measures. J. Clean. Prod. 2019, 238. [CrossRef]

78. Haq, A.N.; Kannan, G. Fuzzy Analytical Hierarchy Process for evaluating and selecting a vendor in a Supply Chain model. Int. J. Adv. Manuf. Technol. 2006, 29, 826-835. [CrossRef]

79. Mokhtar, A.R.M.; Genovese, A.; Brint, A.; Kumar, N. Improving reverse supply chain performance: The role of supply chain leadership and governance mechanisms. J. Clean. Prod. 2019, 216, 42-55. [CrossRef]

80. Dyer, J.H.; Chu, W. The determinants of trust in supplier-automaker relationships in the U.S., Japan, and Korea. J. Int. Bus. Stud. 2000, 31, 259-285. [CrossRef]

81. Onofrei, G.; Nguyen, H.M.; Zhang, M.; Fynes, B. Building supply chain relational capital: The impact of supplier and customer leveraging on innovation performance. Bus. Strategy Environ. 2020, 1-13. [CrossRef]

82. Dahlmann, F.; Roehrich, J.K. Sustainable supply chain management and partner engagement to manage climate change information. Bus. Strategy Environ. 2019, 28, 1632-1647. [CrossRef]

83. Ertz, M.; Durif, F.; Arcand, M. Life after death? Study of goods multiple lives practices. J. Consum. Mark. 2017, 34, 108-118. [CrossRef]

84. Hazen, B.T.; Overstreet, R.E.; Jones-Farmer, L.A.; Field, H.S. The role of ambiguity tolerance in consumer perception of remanufactured products. Int. J. Prod. Econ. 2012, 135, 781-790. [CrossRef]

85. Kuah, A.T.H.; Wang, P. Circular economy and consumer acceptance: An exploratory study in East Southeast Asia. J. Clean. Prod. 2020, 247, 119097. [CrossRef]

86. Laitala, K.; Klepp, I.G.; Haugronning, V.; Throne-Holst, H.; Strandbakken, P. Increasing repair of household appliances, mobile phones and clothing: Experiences from consumers and the repair industry. J. Clean. Prod. 2021, 282, 125349. [CrossRef]

87. Ellen Macarthur Foundation. Towards the Circular Economy Vol. 2: Opportunities for the Consumer Goods Sector. 2013. Available online: https: / www.ellenmacarthurfoundation.org/publications/towards-the-circular-economy-vol-2-opportunitiesfor-the-consumer-goods-sector (accessed on 3 February 2021).

88. Van Weelden, E.; Mugge, R.; Bakker, C. Paving the way towards circular consumption: Exploring consumer acceptance of refurbished mobile phones in the Dutch market. J. Clean. Prod. 2016, 113, 743-754. [CrossRef]

89. Jain, N.; Rathore, A.P.S.; Jain, R.; Yadav, O.P. Maintenance planning based on reliability assessment of multi-state multi-component system. In Proceedings of the IEEE International Conference on Industrial Engineering and Engineering Management, Bangkok, Thailand, 16-19 December 2018; pp. 262-267. [CrossRef]

90. Lei, Y.; Liu, Q.; Shum, S. Warranty pricing with consumer learning. Eur. J. Oper. Res. 2017, 263, 596-610. [CrossRef]

91. Kazancoglu, Y.; Kazancoglu, I.; Sagnak, M. A new holistic conceptual framework for green supply chain management performance assessment based on circular economy. J. Clean. Prod. 2018, 195. [CrossRef]

92. Mugge, R.; Jockin, B.; Bocken, N. How to sell refurbished smartphones? An investigation of different customer groups and appropriate incentives. J. Clean. Prod. 2017, 147, 284-296. [CrossRef]

93. Nassour, A.; Hemidat, S.; Lemke, A.; Elnaas, A.; Nelles, M. Separation by manual sorting at home: State of the art in Germany. In Source Separation and Recycling. The Handbook of Environmental Chemistry; Maletz, R., Dornack, C., Ziyang, L., Eds.; Springer: Cham, Switzerland, 2017; pp. 67-87. [CrossRef]

94. Ghisellini, P.; Cialani, C.; Ulgiati, S. A review on circular economy: The expected transition to a balanced interplay of environmental and economic systems. J. Clean. Prod. 2016, 114, 11-32. [CrossRef]

95. Taghikhah, F.; Voinov, A.; Shukla, N. Extending the supply chain to address sustainability. J. Clean. Prod. 2019, 229, 652-666. [CrossRef] 
96. Bocken, N.M.P.; Bakker, C.; Pauw De, I. Product design and business model strategies for a circular economy. J. Ind. Prod. Eng. 2016, 1015, 20. [CrossRef]

97. Sarkis, J.; Zhu, Q.; Lai, K. An organizational theoretic review of green supply chain management literature. Int. J. Prod. Econ. 2011, 130, 1-15. [CrossRef]

98. Wang, Z.H.; Zhang, B.; Yin, J.H.; Zhang, X. Willingness and behavior towards ewaste recycling for residents in Beijing city, China. J. Clean. Prod. 2011, 19, 977-984. [CrossRef]

99. Laurenti, R.; Martin, M.; Stenmarck, A. Developing adequate communication of waste footprints of products for a circular economy-A stakeholder consultation. Resources 2018, 7, 78. [CrossRef]

100. Ketelsen, M.; Janssen, M.; Hamm, U. Consumers' response to environmentally friendly food packaging-A systematic review. J. Clean. Prod. 2020, 254, 120123. [CrossRef]

101. Young, W.; Hwang, K.; McDonald, S.; Oates, C.J. Sustainable consumption: Green consumer behavior when purchasing products. Sustain. Dev. 2010, 18, 20-31. [CrossRef]

102. Wang, Z.; Akbar, M.; Akbar, A. The interplay between working capital management and a firm's financial performance across the corporate life. Sustainability 2020, 12, 1661. [CrossRef]

103. Jiménez-Parra, B.; Rubio, S.; Vicente-Molina, M.A. Key drivers in the behavior of potential consumers of remanufactured products: A study on laptops in Spain. J. Clean. Prod. 2014, 85, 488-496. [CrossRef]

104. Coskun, S.; Ozgur, L.; Polat, O.; Gungor, A. A model proposal for green supply chain network design based on consumer segmentation. J. Clean. Prod. 2016, 110, 149-157. [CrossRef]

105. Taleizadeh, A.A.; Alizadeh-Basban, N.; Akhavan Niaki, S.T. A closed-loop supply chain considering carbon reduction, quality improvement effort, and return policy under two remanufacturing scenarios. J. Clean. Prod. 2019, 232, 1230-1250. [CrossRef]

106. Patricia, V.L.; van Wassenhove, L.N. Assessing the economic and environmental impact of remanufacturing: A decision support tool for OEM suppliers. Int. J. Prod. Res. 2018, 56, 1662-1674. [CrossRef]

107. Saphores, J.-D.M.; Ogunseitan, O.A.; Shapiro, A.A. Willingness to engage in a proenvironmental behavior: An analysis of e-waste recycling based on a national survey of U.S. Households. Resour. Conserv. Recycl. 2012, 60, 49-63. [CrossRef]

108. Miceli, A.; Hagen, B.; Riccardi, M.P.; Sotti, F.; Settembre-Blundo, D. Thriving, not just surviving in changing times: How sustainability, agility and digitalization intertwine with organizational resilience. Sustainability 2021, 13, 2052. [CrossRef]

109. Hofman, P.S.; Blome, C.; Schleper, M.C.; Subramanian, N. Supply chain collaboration and eco-innovations: An institutional perspective from China. Bus. Strategy Environ. 2020, 29, 2734-2754. [CrossRef]

110. González-Sánchez, R.; Settembre-Blundo, D.; Ferrari, A.M.; García-Muiña, F.E. Main dimensions in the building of the circular supply chain: A literature review. Sustainability 2020, 12, 2459. [CrossRef] 